frequent and valued contributor to the "Journal of Mental Science," his last paper appearing in the April number of this year. He also published several chemical papers in German in the German periodicals. He was an industrious worker, and was possessed of considerable ability. The illness which terminated his death was typhoid fever of a most virulent type. He died Oct. 27,1881 , in the 29 th year of his age.

\title{
DR. PHILLIMORE.
}

Wm. P. Phillimore, M.B., Medical Superintendent of the County Asylum, Nottingham, since 1855, died, aged 60, on the 21 st day of November, 1881 .

MR. GREEN.

Thomas Green, M.R.C.S. and L.S.A., Medical Superintendent of the Birmingham Borough Lunatic Asylum, died on the 29th of November, aged 81.

\section{INDEX MEDICO-PSYCHOLOGICUS.}

\section{JOURNALS AND TRANSACTIONS.}

\author{
EN GLISH.
}

The Journal of Mental Science. London. Quarterly.

The Journal of Psychological Medicine and Mental Pathology. London. Semi-Annual.

Brain. A Journal of Neurology. London. Quarterly.

Mind. A Quarterly Review of Psychology and Philosophy. London.

\section{British Guiana.}

The Asylum Journal. Berbice. Monthly.

\section{AMERICAN.}

The American Journal of Insanity. Utica, N.Y. Quarterly. The Journal of Nervous and Mental Disease. Chicago. Quarterly.

Proceedings of the Association of Medical Officers of American Institutions for Idiotic and Feeble-Minded Persons. Philadelphia. Annual.

Neurological Contributions. New York. Quarterly. The Quarterly Journal of Inebriety. Hartford, Conn.

The Alienist and Neurologist. St. Louis, Misso.

\section{FRENCH.}

Annales Médico-Psychologiques. Paris. Bi-Monthly.

Annales d'Hygiène Publique et de Médecine Légale. Paris. Monthly. Archives de Neurologie. Paris. Quarterly.

L'Encéphale. Paris. Quarterly.

BELGIAN.

Bulletin de la Société de Médecine Mentale de Belgique. Gand. Quarterly. 